\title{
Grapevine red blotch virus: Absence in Swiss Vineyards and Analysis of Potential Detrimental Effect on Viticultural Performance
}

\author{
Jean-Sébastien Reynard, ${ }^{\dagger}$ Agroscope; Justine Brodard and Nathalie Dubuis, Agroscope; Vivian Zufferey, Agroscope; Olivier Schumpp, \\ Agroscope; Santiago Schaerer, Agroscope; and Paul Gugerli, Agroscope
}

\begin{abstract}
Grapevine red blotch virus (GRBV) is a recently described virus that infects grapevine. Little information is available on the possible occurrence and distribution outside North America. Therefore, we surveyed commercial vineyards from the three major grape-growing regions in Switzerland to determine the presence or absence of GRBV. In total, 3,062 vines were analyzed by polymerase chain reaction. None of the vines tested positive for GRBV, suggesting the absence of GRBV from Swiss vineyards. We also investigated whether GRBV was present in 653 grapevine accessions in the Agroscope grapevine virus collection at Nyon, including dominantly Swiss (457) but also international accessions. Only six referential accessions were infected by GRBV, all originating from the United States, whereas all others from 10 European and 8

non-European origins tested negative. High-throughput sequencing analysis of Zinfandel A2V13, in the collection since 1985, confirmed close similarity of GRBV isolate Z_A2V13 to American isolates according to genomes deposited in GenBank. Because the Zinfandel A2V13 reference was also maintained grafted on the leafroll virus indicator Vitis vinifera 'Gamay', we evaluated the effect of GRBV on viticultural performance over a 3-year period. Our results showed clear detrimental effects of GRBV on grapevine physiology (vine vigor, leaf chlorophyll content, and gas exchange) and fruit quality. These findings underscore the importance of implementation of GRBV testing worldwide in certification and quarantine programs to prevent the dissemination of this virus.
\end{abstract}

Grapevine cultivation in Switzerland has a long history and can be traced back at least to the Roman period 2,000 years ago. Currently, grapevine is cultivated on over 15,000 ha and represents an important agricultural commodity. More than 60 different viruses are reported to infect grapevine (Martelli 2014), and more than a dozen viruses are also identified in Swiss vineyards. Grapevine fanleaf virus and Grapevine leafroll-associated virus (GLRaV) are particularly important (Reynard and Gugerli 2012) but stem pitting-, stem grooving-, and corky bark-associated viruses are also detrimental.

In contrast to fanleaf degeneration that was first described more than 150 years ago (Andret-Link et al. 2004), grapevine red blotch is a recently identified viral disease that was first recognized as a disease in 2008, when foliar symptoms similar to leafroll were observed in Napa Valley, CA on vines testing negative for known GLRaV (Calvi 2011). In 2012, Grapevine red blotch virus (GRBV) was discovered independently in California and New York (Al Rwahnih et al. 2012; Krenz et al. 2012) and was later demonstrated to be the causal agent of red blotch disease (Fuchs et al. 2015). This virus has also been referred to as Cabernet franc-associated virus (Krenz et al. 2012), Grapevine red leaf-associated virus (Poojari et al. 2013), and Grapevine geminivirus (Seguin et al. 2014). GRBV is a circular, single-stranded DNA virus. Because of the specific genome organization and genetic divergence from any other known related Geminivirus spp., a new genus was proposed for GRBV. Therefore, the International Committee on Taxonomy of Viruses recently approved the creation of the genus Grablovirus within the family Geminiviridae (Varsani et al. 2017). GRBV is currently the only member of this genus.

After discovery of the virus, surveys demonstrated a high prevalence of GRBV in all major grape-growing regions across the United States (Krenz et al. 2014). Consequently, GRBV is now recognized as a major economic threat to the U.S. wine industry (Ricketts et al. 2017). Furthermore, GRBV is observed on native and wild Vitis spp. collected around infected vineyards, indicating that this virus is not only spread by viticultural practices (i.e., vegetative propagation)

${ }^{\dagger}$ Corresponding author: J.-S. Reynard;

E-mail: jean-sebastien.reynard@ agroscope.admin.ch

Accepted for publication 2 November 2017.

C) 2018 The American Phytopathological Society but also naturally (Bahder et al. 2016b; Perry et al. 2016). Although significant advances have been made in understanding GRBV since its discovery in 2012, the epidemiology is poorly understood. Questions also remain about the origins of this emergent pathogen and its distribution outside North America. Here, we report the results from a large-scale survey that indicates that GRBV is not present in three primary Swiss vine-growing regions. We also report on the substantial detrimental effects of GRBV on viticultural performance of infected Gamay vines.

\section{Materials and Methods}

Reference and test samples. GRBV reference samples were collected from the Agroscope grapevine virus collection in Switzerland (Gugerli et al. 2009; Reynard and Gugerli 2015). Samples for the surveys consisted of two petioles from basal leaves, collected from two separate canes of a vine. During the summer months of 2014, 2015 , and 2016 in commercial Swiss vineyards, 3,062 individual plants were sampled, including 330 vines from Valais, 921 vines from Ticino, and 1,811 from Vaud. Most of the sampled vines presented symptoms of reddening or yellowing but asymptomatic vines were also randomly assessed. Additionally, 653 accessions from the Agroscope grapevine virus collection were tested in 2015 .

Nucleic acid extraction and GRBV detection. Fresh petiole tissue samples of $80 \mathrm{mg}$ were ground using a TissueLyser (Qiagen) and processed directly for nucleic acid extraction. DNA was extracted using a BioSprint semiautomated platform (Qiagen) according to the manufacturer's protocols. DNA was finally eluted in $200 \mu \mathrm{l}$ of water and stored at $-20^{\circ} \mathrm{C}$ until analysis. Purified DNA was screened for GRBV by polymerase chain reaction (PCR) using the primers Repfor and Reprev, as published (Krenz et al. 2014). In addition to those primers for virus detection, primers NS7 and NS8, specific for detecting a plant internal control (18S ribosomal DNA [rDNA]), were added to the multiplex reaction (White et al. 1990). Amplified DNA was separated on $1.5 \%$ agarose gels and stained with ethidium bromide. The expected amplicon size was 318 bp for GRBV and 377 bp for $18 \mathrm{~S}$ rDNA. GRBV amplicons were eluted from the gels using the Wizard system (Promega) and then were Sanger sequenced, using ampliconspecific primers, by Fasteris SA.

High-throughput sequencing. High-throughput sequencing (HTS) analysis was performed on one Gamay plant (number 9115) that was graft inoculated using Zinfandel A2V13. Petioles were collected in September 
2016. Total RNA was extracted using a rapid cetyltrimethylammonium bromide protocol (Gambino et al. 2008). Small RNA (sRNA) were selected using polyacrylamide gel and used for Illumina sequencing of sRNA (Fasteris SA). The resulting sRNA library was screened for viruses and viroids using two different semiautomated pipelines: Truffle (Visser et al. 2016) and VirusDetect (Zheng et al. 2017). De novo reconstruction of the GRBV genome was performed by assembling reads ranging from 20 to 25 nucleotides (nt) using Velvet 1.2.10 (Zerbino and Birney 2008). Validation of the complete GRBV genome was performed by mapping raw reads using Bowtie (Langmead et al. 2009). Confirmations of the different agents identified by HTS were obtained by PCR using specific primers designed from produced contigs.

Vine physiology and fruit composition. Graft-inoculation experiments with Zinfandel A2V13 were performed in 1999 on Vitis vinifera 'Gamay'. Two blocks of three graft-inoculated Gamay plants each (numbers 9115, 9116, 9117, 9026, 9027, and 9028) were planted in 2000 in the Agroscope grapevine virus collection adjacent to two block of healthy controls (grafted Gamay plants, numbers 9106, 9107, 9108, 9020, 9021, and 9022). Grapevines were cultivated following industry standard practices. Observations on GRBV effects on viticultural performance were performed on these Gamay plants. Several parameters were assessed during the 2014, 2015, and 2016 seasons. During winters, pruning wood was weighed for each individual plant. Gas exchange measurements were conducted on two adult nonsenescent leaves per plant using a Li-Cor 6400 XT portable photosynthesis system, as described by Zufferey et al. (2011). Net photosynthesis, transpiration, and leaf stomatal conductance were measured at saturating light (photon flux density $>1,800$ $\mathrm{mmol} \mathrm{m} \mathrm{m}^{-2} \mathrm{~s}^{-1}$ ) on healthy leaves without virus symptoms. Relative leaf chlorophyll concentrations were measured on mature leaves using a chlorophyll tester called $\mathrm{N}$-tester (Yara, France); the measurements (expressed as $\mathrm{N}$-tester units) were taken between June and September. At commercial maturity, grape berries were collected and weighed individually for each plant. Grape berries were then manually pressed to extract juices, and fruit composition parameters were measured using Fourier transform infrared spectroscopy (WineScan; FOSS NIRSystems). Measurements of total anthocyanin content were performed according to the Glories method (Ribéreau-Gayon P. et al. 2006). Briefly, 100 berries/plant were crushed in a blender, and $50 \mathrm{~g}$ of berry skins was extracted at $\mathrm{pH} 1$ and the absorbance recorded at $280 \mathrm{~nm}$.

Physiological and fruit composition data were analyzed using $\mathrm{R}$ software (https://www.r-project.org/). One-way analysis of variance was used to determine differences between treatments for the measured variables.

\section{Results}

Definition of a GRBV reference. After the first report of GRBV in 2012 and the development of a diagnostic method (Krenz et al. 2014), we monitored three American accessions in the Agroscope virus collection: Emperor A2V18 (numbers 9077, 9078, and 9079),
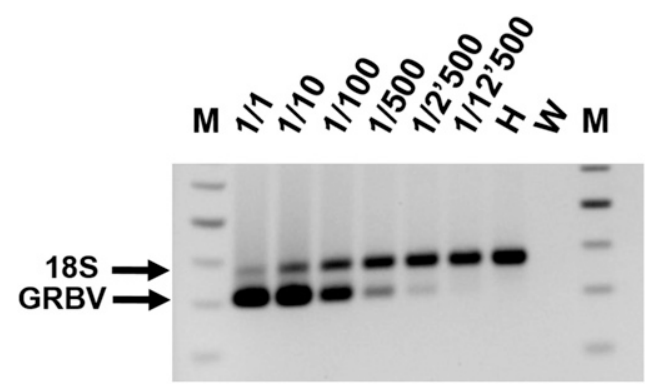

Fig. 1. Agarose gel electrophoretic analysis of DNA fragments amplified by polymerase chain reaction (PCR) from nucleic acid extractions combining different ratio of Grapevine red blotch virus (GRBV)-infected and noninfected petioles. Primers used in the PCR were specific to GRBV (318 bp) and to grapevine 18S ribosomal RNA gene (377 bp). Lane M, 100-bp DNA ladder; lane 1/1, positive infected vine; lanes $1 / 10$ to $1 / 12^{\prime} 500$, serial dilutions of the positive control; lane $\mathrm{H}$, healthy vine; and lane $\mathrm{W}$, water control.
Thompson seedless A2V22 (numbers 9080, 9081, and 9082), and Zinfandel A2V13 (numbers 9083, 9084, and 9085). Dr. Goheen from the University of California-Davis kindly originally donated these accessions in the 1980s. Emperor and Thompson seedless were infected with GLRaV-4 (GLRaV-4 strain 5 and GLRaV-4, respectively) and with a nonidentified virus consisting of isometric particles (Gugerli and Ramel 1993). None of these viruses were found in samples of Zinfandel A2V13. However, the Zinfandel A2V13 and Emperor vines tested positive for GRBV. Because Zinfandel A2V13 was not coinfected with other closteroviruses, this accession was ultimately retained as a GRBV reference. Sequencing of the amplified Rep gene amplicon (318 nt) showed 100\% identity with some GRBV isolates available in GenBank. The GRBV isolate from the Zinfandel was then also analyzed by HTS to obtain the complete genome sequence. Deep sequencing of sRNA generated approximately 32 million reads ( 20 to $25 \mathrm{nt}$ in length). An approach combining the results of de novo assembly and contigs extension by mapping produced a contig 3,206 bp in length, representing the complete genome of GRBV. To this GRBV genome, 197,562 reads (approximately $0.6 \%$ ) were mapped. The full genome sequence of this isolate (GRBV Z_A2V13, accession number MF276895) showed 92 to $99 \%$ identity with other GRBV genomes. The GRBV isolate $\mathrm{Z} \_\mathrm{A} 2 \mathrm{~V} 13$ presented in this work differed from the reference GRBV sequence in GenBank (NC_022002.1) at 21 nucleotide positions. Furthermore, data from the sRNA library were analyzed for other viral pathogens. In addition to GRBV, one virus (Grapevine rupestris stem pitting-associated virus [GRSPaV] ) and two viroids (Hop stunt viroid [HSVd] and Grapevine yellow speckle viroid 1 [GYSVd1]) were detected in this accession but GLRaV were not. HTS data clearly demonstrated that no Closterovirus sp. infects Zinfandel A2V13.

Samples processing. Composite sampling is the bulking of tissue from multiple plants into a single sample for nucleic acid extraction and testing. In preliminary tests, dilutions of GRBV-infected tissue in healthy tissue were extracted and tested for GRBV (Fig. 1). Based on these tests, the assay used in this study consistently detected 1 individual GRBV-positive vine when in a composite sample consisting of 10 vines. Therefore, petioles from 10 different vines were combined for total nucleic acid extraction. When a composite sample produced a positive signal, the 10 subsamples representing individual vines were tested separately.

Survey of commercial Swiss vineyards. In a monitoring of grapevine yellows in Swiss vineyards, 722 individual samples were simultaneously tested for GRBV. A further 2,340 vines were sampled independently in commercial vineyards and tested as composite samples representing 10 vines. In total, 3,062 vines were tested from the three major grape-growing regions of Switzerland (Fig. 2). The surveyed regions represented approximately $60 \%$ (9,000 ha) of vineyard area in Switzerland. All these samples tested negative for GRBV and the internal control fragment was amplified in every reaction.

Survey of GRBV in the Agroscope grapevine virus collection. We tested 653 accessions, dominantly infected by leafroll viruses collected in Swiss vineyards $(n=447)$ but that, overall, originated from 19 different grape-growing countries (153 accessions from European origin and 53 accessions from overseas). Of these 653 accessions, only 6 , including the references mentioned above, were infected by GRBV. For each positive accession, individual testing of all three replicates in the collection gave consistent positive PCR signals. Sequencing of the amplified PCR products (318 nt) from the six GRBV isolates revealed that they were all identical to the corresponding region of the reference GRBV sequence in GenBank (NC_022002.1). All accessions that tested positive for GRBV, except for the Zinfandel, were also coinfected by leafroll viruses and all were of U.S. origin.

Effects of GRBV on viticultural performance. All six GRBVgraft-inoculated Gamay plants tested positive in PCR for GRBV and three other viruses or viroids identified using HTS (i.e., GRSPaV, HSVd, and GYSVd1). By contrast, the six control plants (grafted Gamay plants) were positive for HSVd and GYSVd1. One block of control plants was positive for GRSPaV while the second block was negative for this virus. We did not measure any significant differences between 
the two healthy blocks (data not shown). Furthermore, all control and GRBV-inoculated plants have been tested negative for other common grapevine viruses (i.e., nepoviruses and GLRaV). Gas exchange was evaluated using net photosynthesis, transpiration, and stomatal conductance. These three physiological parameters were measured in mid-July 2014 and 2016, before the development of foliar symptoms. Net photosynthesis and transpiration were higher in noninoculated than in inoculated grapevines (Table 1). With GRBV inoculation, the net photosynthesis rate was reduced approximately $25 \%$. Measurements performed during symptomatic stages showed a similar effect (data not shown). Stomatal conductance was $44 \%$ lower in GRBV-inoculated than in noninoculated plants in 2014 but no significant differences were observed in 2015 and 2016. During 2015, the three gas exchange parameters were measured earlier in the season (June), and no significant differences were observed between graftinoculated and control plants (Table 1).

Chlorophyll concentration, measured every second week during the 3 years, was not significantly different between GRBV-inoculated and noninoculated plants in June. However, beginning in July and continuing to harvest, a highly significant decrease in chlorophyll contents was observed in the GRBV-inoculated plants (Fig. 3).

Vegetative growth for 2 years was measured by weighing pruning wood per plant, and GRBV-inoculated vines showed weight reductions of $35 \%(F=9.8, P=0.008)$ and $33 \%(F=24.0, P=0.0002)$ in 2015 and 2016, respectively.

Fruit composition at harvest was affected in each of the three seasons by GRBV (Table 2). Compared with noninoculated vines, juices from GRBV-inoculated vines were significantly lower in total soluble solids, with an average (over the three seasons) reduction of $11 \%$. The $\mathrm{pH}$ of the juices was higher in inoculated than in noninoculated berries. For the three harvests, malic acid contents were higher in inoculated than in noninoculated berries, by an average of $56 \%$. By contrast, tartaric acid content was significantly lower in inoculated berries over the three harvests. Finally, the amounts of total berry anthocyanins measured in 2016 showed an approximately 50\% reduction in inoculated berries compared with noninoculated ones. Juice nitrogen concentration (yeast-assimilable nitrogen) and yields were not significantly different between the variants (data not shown).

\section{Discussion}

PCR performed on pooled petioles was demonstrated reliable for routine surveys of GRBV in grapevine, reducing labor and cost. The GRBV-infected accession Zinfandel A2V13 was characterized in detail and was used in this work as a GRBV reference isolate, serving as the positive control required for reliable routine GRBV monitoring. With only 21 different nucleotide positions compared with the reference GRBV sequence in GenBank, GRBV Z_A2V13 is closely related to American isolates, although GRBV was imported in 1985 from the United States to Switzerland as a supposed leafroll diseased reference and preserved in our collection since that time. At that time, however, leafroll-associated viruses were not yet identified or characterized. The discovery of GRBV in this accession explains the leafroll-like symptoms and the many negative results of serological and electron microscope investigations. Emperor A2V18, also imported in 1985 from the United States, was at least doubly infected by GRBV and GLRaV-4. This accession expresses severe leafroll-like symptoms, potentially due to a synergism between the two viruses, possibly a characteristic of the "White Emperor disorder" (Goheen et al. 1958).

The large-scale survey in this work demonstrated the absence of detectable GRBV in the three major Swiss grapevine-growing regions. Together with the survey of the Agroscope virus collection, these results suggest that the virus is not present in Swiss vineyards. Absence of spread of GRBV in the Agroscope grapevine virus collection for more than 30 years also indicated the lack of vector or contact transmission. Thus, the epidemiological situation in Switzerland sharply contrasts with that in North America, in which the virus is actively spreading (Al Rwahnih et al. 2015b; Brannen et al. 2013; Krenz et al. 2014; Sudarshana et al. 2015), presumably transmitted

Table 1. Grapevine red blotch virus (GRBV) effects on gas exchange parameters in Vitis vinifera 'Gamay': net photosynthesis $\left(\mathrm{A}_{\mathrm{N}}\right)$, stomatal conductance $\left(\mathrm{g}_{\mathrm{s}}\right)$ and transpiration $(\mathrm{E})^{\mathrm{a}}$

\begin{tabular}{|c|c|c|c|}
\hline Date & $\begin{array}{c}\mathrm{A}_{\mathrm{N}}\left(\boldsymbol{\mu m o l ~ C O _ { 2 }}\right. \\
\left.\mathrm{m}^{-2} \mathrm{~s}^{-1}\right)\end{array}$ & $\begin{array}{c}\mathrm{g}_{\mathrm{s}}\left(\mathrm{mol} \mathrm{CO} \mathrm{CO}_{2}\right. \\
\left.\mathrm{m}^{-2} \mathrm{~s}^{-1}\right)\end{array}$ & $\begin{array}{c}\mathbf{E}(\mathrm{mmol} \\
\left.\mathrm{H}_{2} \mathrm{Om}^{-2} \mathrm{~s}^{-1}\right)\end{array}$ \\
\hline \multicolumn{4}{|l|}{18 July 2014} \\
\hline GRBV (-) & $16.7 \pm 1.0$ & $0.25 \pm 0.03$ & $5.0 \pm 0.4$ \\
\hline GRBV (+) & $12.1 \pm 1.4$ & $0.14 \pm 0.04$ & $3.3 \pm 0.7$ \\
\hline Significance & $* * *$ & $* * *$ & $*$ \\
\hline \multicolumn{4}{|l|}{17 June 2015} \\
\hline GRBV (-) & $14.1 \pm 0.8$ & $0.23 \pm 0.03$ & $3.4 \pm 0.3$ \\
\hline GRBV (+) & $12.6 \pm 2.8$ & $0.21 \pm 0.06$ & $3.2 \pm 0.7$ \\
\hline \multicolumn{4}{|l|}{ Significance } \\
\hline \multicolumn{4}{|l|}{20 July 2016} \\
\hline GRBV (-) & $16.6 \pm 1.0$ & $0.29 \pm 0.03$ & $6.1 \pm 0.3$ \\
\hline GRBV (+) & $12.6 \pm 1.3$ & $0.25 \pm 0.03$ & $5.2 \pm 0.5$ \\
\hline Significance & $* *$ & & $*$ \\
\hline
\end{tabular}

${ }^{\mathrm{a}}$ Measurements were performed on three dates for noninfected, GRBV (-) and inoculated plants, GRBV (+). Data are expressed as the mean \pm standard deviation. Noninfected $=$ six plants and GRBV-inoculated $=$ six plants. Significant differences are indicated by *,**, and *** for significance at $P \leq$ $0.05,0.01$, and 0.001 , respectively.

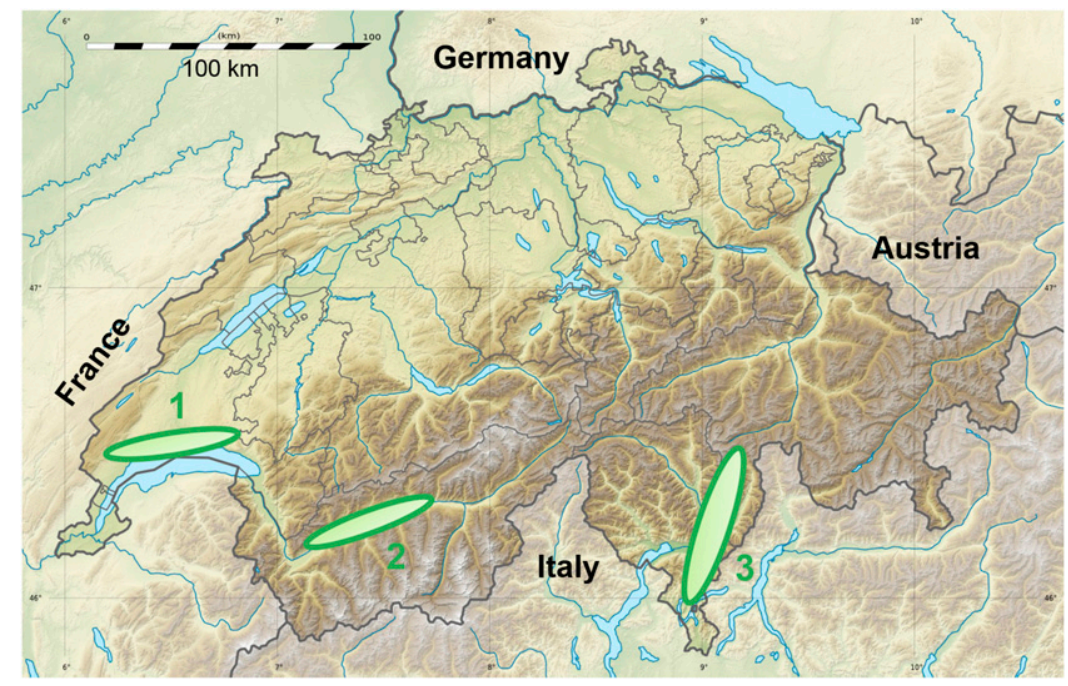

Fig. 2. Map of Switzerland and the surrounding countries. Large-scale Grapevine red blotch virus survey was performed in three major grape-growing regions. Number of vines tested is indicated in parentheses. Region $1=$ Vaud $(1,811)$, region $2=$ Valais $(330)$, and region $3=$ Ticino (921). 
through insect vectors (Cieniewicz et al. 2017; Sudarshana et al. 2015). The cornered alfalfa treehopper Spissistilus festinus was recently shown to transmit the virus under experimental conditions (Bahder et al. 2016a). However, S. festinus is a Nearctic species, thus probably absent from Europe. Canada represents an intermediate situation, because a recent large-scale survey revealed a low incidence of GRBV in British Columbia (Poojari et al. 2017). Recent reports on GRBV infecting grapevine in South Korea (Lim et al. 2016) and in India (GenBank accession KU522121) suggest a potential spread of GRBV outside North America. Because GRBV has not been reported yet in any European countries, the virus is on the alert list of the European and Mediterranean Plant Protection Organization (www.eppo.int/). In the absence of reports of GRBV infection in the Old World, one can speculate that GRBV moved from an indigenous wild host plant into grapevine sometime after the introduction in the 18th century of $V$. vinifera to North America.

On the other hand, GRBV-infected Zinfandel and Emperor accessions were introduced from the United States in 1985. This introduction highlights that GBRV was already in North America in the 1980s, although only recently identified (Krenz et al. 2014). Therefore, GRBV has been overlooked for decades because of the lack of a detection test and symptoms similar to those of GLRaV. Analogous conclusions have been drawn from a previous study reporting the presence of GRBV in $V$. vinifera 'Early Burgundy' kept in a herbarium assembled in 1940 from California vineyards, suggesting that GRBV is not a recently evolved virus (Al Rwahnih et al. 2015a).

In the inoculation experiment, control plants were infected with GRSPaV, HSVd, and GYSVd1. However, no specific symptoms were observed on these plants. This finding was not surprising given that those agents are ubiquitous in grapevines and $V$. vinifera is often infected without symptoms (Little and Rezaian 2003; Reynard and Gugerli 2012; Szychowski et al. 1991). GRBV-inoculated Gamay plants were also coinfected with GRSPaV, HSVd, and GYSPVd1. Consequently, we attribute the noticeable disease symptoms and effect on vine performance to GRBV, although recognizing that synergistic effects could occur. GRBV affected grapevine physiology and fruit composition. Under the temperate Swiss climate, foliar symptoms on Gamay grapevine appeared during summer, usually at the beginning of August (veraison). Photosynthesis rates declined before symptoms appeared on inoculated vines compared with healthy controls, and GRBV inoculation diminished vine vigor based on the weight of pruning wood. We also found that GRBV negatively affected

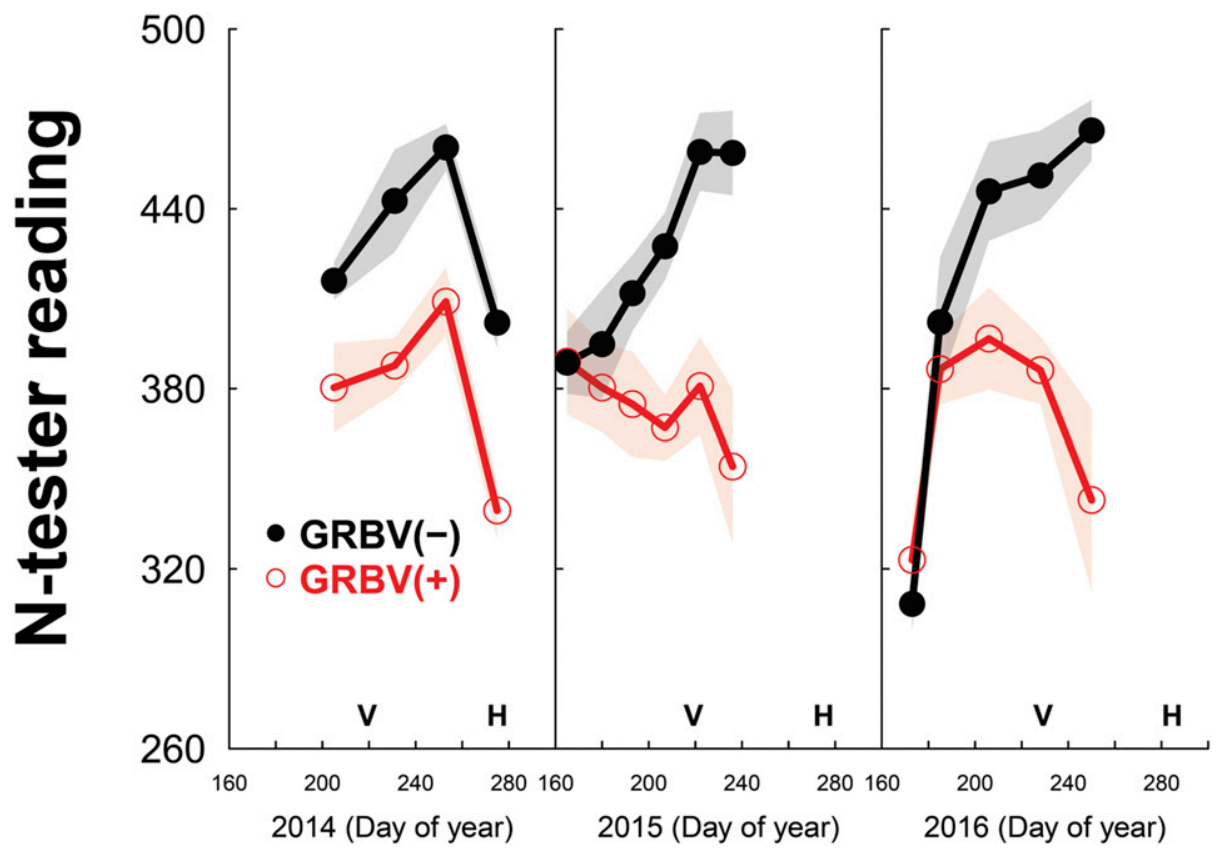

Fig. 3. Chlorophyll relative contents (N-tester reading) in noninfected (black line and filled circles) and Grapevine red blotch virus (GRBV)-inoculated Vitis vinifera 'Gamay' (gray line and open circles) over three seasons (2014 to 2016). Letters $V$ and $H$ represent dates of veraison (i.e., change of fruit color from green to blue) and harvest, respectively. Data are expressed as the mean \pm standard deviation (shading). Noninfected $=$ six plants and GRBV-inoculated $=$ six plants.

Table 2. Effect of Grapevine red blotch virus (GRBV) on yields and fruit composition at harvest of Vitis vinifera 'Gamay' in three consecutive seasons (2014 to 2016) $)^{\mathrm{a}}$

\begin{tabular}{|c|c|c|c|c|c|c|}
\hline Season & Yield (kg/vine) & Soluble solids ( $\left.{ }^{\circ} \mathrm{Brix}\right)$ & pH & Tartaric acid (g/liter) & Malic acid (g/liter) & Anthocyanins (mg/liter) \\
\hline \multicolumn{7}{|l|}{2014} \\
\hline GRBV (-) & $0.7 \pm 0.4$ & $20.6 \pm 0.5$ & $3.0 \pm 0.03$ & $8.2 \pm 0.4$ & $7.0 \pm 0.8$ & n.a. \\
\hline GRBV (+) & $0.7 \pm 0.2$ & $18.1 \pm 0.7$ & $3.2 \pm 0.06$ & $7.1 \pm 0.4$ & $8.2 \pm 0.7$ & n.a. \\
\hline Significance & & $* * *$ & $* *$ & $* * *$ & $*$ & \\
\hline \multicolumn{7}{|l|}{2015} \\
\hline GRBV (-) & $1.4 \pm 0.5$ & $22.3 \pm 0.4$ & $3.1 \pm 0.05$ & $7.9 \pm 0.2$ & $1.9 \pm 0.4$ & n.a. \\
\hline GRBV (+) & $1.2 \pm 0.3$ & $19.3 \pm 0.6$ & $3.3 \pm 0.10$ & $6.2 \pm 0.7$ & $4.0 \pm 0.6$ & n.a. \\
\hline Significance & & $* * *$ & $* * *$ & $* * *$ & $* * *$ & \\
\hline \multicolumn{7}{|l|}{2016} \\
\hline GRBV (-) & $1.8 \pm 0.4$ & $22.0 \pm 1.3$ & $3.0 \pm 0.05$ & $7.5 \pm 0.3$ & $3.6 \pm 0.3$ & $663 \pm 16$ \\
\hline GRBV (+) & $1.5 \pm 0.2$ & $20.1 \pm 0.2$ & $3.2 \pm 0.03$ & $6.2 \pm 0.4$ & $5.7 \pm 0.5$ & $332 \pm 37$ \\
\hline Significance & & $*$ & $* *$ & $* *$ & $* * *$ & $* * *$ \\
\hline
\end{tabular}

${ }^{a}$ Noninfected $=$ six plants and GRBV-inoculated $=$ six plants. Data are expressed as the mean \pm standard deviation; $n$.a. $=$ not available. Significant differences are indicated by $* * *$, and $* * *$ for significance at $P \leq 0.05,0.01$, and 0.001 , respectively. 
the relative leaf chlorophyll concentration. However, reduced carbon assimilation did not correlate with low crop yields. We found that GRBV also delayed fruit maturation, with a reduction in sugar accumulation and an increase in malic acid concentrations, similar to findings in studies by others (Calvi 2011; Poojari et al. 2013). Tartaric acid content in juice was reduced in response to GRBV, with a consequent high $\mathrm{pH}$ in the juices, which has also been reported for leafroll disease (Mannini et al. 2012; Martínez et al. 2016). In our study, GRBV was also negatively correlated with total berry anthocyanin levels, consistent with a recent finding of GRBV effects on berry development and ripening pathways (Blanco-Ulate et al. 2017).

In conclusion, our results show a clear detrimental effect of GRBV on grapevine physiology and fruit quality. Furthermore, based on our results, GRBV was not detected in Swiss vineyards and, therefore, GRBV should be considered a quarantine pathogen for Switzerland. As a precautionary measure, all accessions infected with GRBV were eliminated from our collection. To the best of our knowledge, this study is the first large-scale GRBV survey in vineyards outside North America. Further large-scale studies in other major wine-growing countries, particularly from the Old World, are necessary to evaluate more precisely the global distribution and provide further clues about the origins of this intriguing virus.

\section{Acknowledgments}

Our work is dedicated to the memory of Jean-Jacques Brugger, who passed away in 2015. He was the longstanding curator of our Agroscope grapevine virus collection at Nyon. This study would never have been possible without his dedicated work and passion. We thank H. Johnston, L. Grosu-Duchène, and P. Crausaz for their technical assistance; F. Lorenzini and his team for their help in collecting and interpreting fruit composition data; and our international colleagues for their valuable contributions in providing grapevine accessions for our collection.

\section{Literature Cited}

Al Rwahnih, M., Dave, A., Anderson, M., Uyemoto, J., and Sudarshana, M. R. 2012. Association of a circular DNA virus in grapevines affected by red blotch disease in California. Pages 104-105 in: Proc. 17th Congr. Int. Counc. Study Virus Virus-like Dis. Grapevine (ICVG), Davis, CA.

Al Rwahnih, M., Rowhani, A., and Golino, D. 2015a. First report of Grapevine red blotch-associated virus in archival grapevine material from Sonoma County, California. Plant Dis. 99:895.

Al Rwahnih, M., Rowhani, A., Golino, D. A., Islas, C. M., Preece, J. E., and Sudarshana, M. R. 2015b. Detection and genetic diversity of Grapevine red blotch-associated virus isolates in table grape accessions in the National Clonal Germplasm Repository in California. Can. J. Plant Pathol. 37:130-135.

Andret-Link, P., Laporte, C., Valat, L., Ritzenthaler, C., Demangeat, G., Vigne, E., Laval, V., Pfeiffer, P., Stussi-Garaud, C., and Fuchs, M. 2004. Grapevine fanleaf virus: Still a major threat to the grapevine industry. J. Plant Pathol. 86:183-195.

Bahder, B. W., Zalom, F. G., Jayanth, M., and Sudarshana, M. R. 2016a. Phylogeny of geminivirus coat protein sequences and digital PCR Aid in Identifying Spissistilus festinus as a vector of Grapevine red blotch-associated virus. Phytopathology 106:1223-1230.

Bahder, B. W., Zalom, F. G., and Sudarshana, M. R. 2016b. An evaluation of the flora adjacent to wine grape vineyards for the presence of alternative host plants of Grapevine red blotch-associated virus. Plant Dis. 100:1571-1574.

Blanco-Ulate, B., Hopfer, H., Figueroa-Balderas, R., Ye, Z., Rivero, R. M., Albacete, A., Perez-Alfocea, F., Koyama, R., Anderson, M. M., Smith, R. J., Ebeler, S. E., and Cantu, D. 2017. Red blotch disease alters grape berry development and metabolism by interfering with the transcriptional and hormonal regulation of ripening. J. Exp. Bot. 68:1225-1238.

Brannen, P. M., Deom, C. M., Westmoreland, M., Collins, P., Alabi, O. J., and Rayapati, N. 2013. Prevalence of grapevine (Vitis vinifera) viruses in Georgia. (Abstr.) Phytopathology 103:S2.20.

Calvi, B. L. 2011. Effects of Red-Leaf Disease on Cabernet Sauvignon at the Oakville Experimental Vineyard and Mitigation by Harvest Delay and Crop Adjustment. University of California, Davis.

Cieniewicz, E. J., Pethybridge, S. J., Gorny, A., Madden, L. V., McLane, H., Perry, K. L., and Fuchs, M. 2017. Spatiotemporal spread of Grapevine red blotchassociated virus in a California vineyard. Virus Res. 241:156-162.

Fuchs, M., Krenz, B., Yepes, L. M., Thompson, J., McLane, H., and Perry, K. L. 2015. Is Grapevine red blotch-associated virus the causal agent of red blotch disease? Pages 72-73 in: Proc. 18th Congr. Int. Counc. Study Virus Viruslike Dis. Grapevine (ICVG), Ankara, Tukey.

Gambino, G., Perrone, I., and Gribaudo, I. 2008. A rapid and effective method for RNA extraction from different tissues of grapevine and other woody plants. Phytochem. Anal. 19:520-525.

Goheen, A. C., Harmon, F. N., and Weinberger, J. H. 1958. Leafroll (White Emperor disease) of grapes in California. Phytopathology 48:51-54.
Gugerli, P., Brugger, J. J., Ramel, M. E., and Besse, S. 2009. Grapevine virus collection at Nyon: A contribution to a putative network of a worldwide grapevine virus reference collection. Pages 40-41 in: Proc. 16th Congr. Int. Counc. Study Virus Virus-like Dis. Grapevine (ICVG), Dijon, France.

Gugerli, P., and Ramel, M. E. 1993. Grapevine leafroll associated virus II analyzed by monoclonal antibodies. Pages 23-24 in: Extended Abstr. 11th Meeting ICVG, Montreux, Switzerland. P. Gugerli, ed. Federal Agricultural Research Station of Changins, Nyon, Switzerland.

Krenz, B., Thompson, J. R., Fuchs, M., and Perry, K. L. 2012. Complete genome sequence of a new circular DNA virus from grapevine. J. Virol. 86:7715.

Krenz, B., Thompson, J. R., McLane, H. L., Fuchs, M., and Perry, K. L. 2014. Grapevine red blotch-associated virus is widespread in the United States. Phytopathology 104:1232-1240.

Langmead, B., Trapnell, C., Pop, M., and Salzberg, S. L. 2009. Ultrafast and memory-efficient alignment of short DNA sequences to the human genome. Genome Biol. 10:R25.

Lim, S., Igori, D., Zhao, F., Moon, J. S., Cho, I. S., and Choi, G. S. 2016. First report of Grapevine red blotch-associated virus on grapevine in Korea. Plant Dis. 100:1957.

Little, A., and Rezaian, M. A. 2003. Grapevine viroids. Pages 195-206 in: Viroids. A. Hadidi, R. Flores, J. W. Randles, and J. S. Semancik, eds. CSIRO Publishing, Collingwood, Australia.

Mannini, F., Mollo, A., and Credi, R. 2012. Field performance and wine quality modification in a clone of Vitis vinifera cv. Dolcetto after GLRaV-3 elimination. Am. J. Enol. Vitic. 63:144-147.

Martelli, G. P. 2014. Directory of virus and virus-like diseases of the grapevine and their agents. J. Plant Pathol. 96:1-136.

Martínez, L., Miranda, C., Royo, J. B., Urrestarazu, J., Martínez de Toda, F., Balda, P., and Santesteban, L. G. 2016. Direct and indirect effects of three virus infections on yield and berry composition in grapevine (Vitis vinifera L.) cv. 'Tempranillo'. Sci. Hortic. (Amsterdam) 212:20-28.

Perry, K. L., McLane, H., Hyder, M. Z., Dangl, G. S., Thompson, J. R., and Fuchs, M. F. 2016. Grapevine red blotch-associated virus is present in free-living Vitis spp. proximal to cultivated grapevines. Phytopathology 106:663-670.

Poojari, S., Alabi, O. J., Fofanov, V. Y., and Naidu, R. A. 2013. A leafhoppertransmissible DNA virus with novel evolutionary lineage in the family geminiviridae implicated in grapevine redleaf disease by next-generation sequencing. PLoS One 8:e64194.

Poojari, S., Lowery, D. T., Rott, M., Schmidt, A. M., and Úrbez-Torres, J. R. 2017. Incidence, distribution and genetic diversity of Grapevine red blotch virus in British Columbia. Can. J. Plant Pathol. 39:201-211

Reynard, J. S., and Gugerli, P. 2012. Current status of major grapevine viruses in La Côte vineyards of Switzerland. Pages 74-75 in: Proc. 17th Congr. Int. Counc. Study Virus Virus-like Dis. Grapevine (ICVG), Davis, CA.

Reynard, J. S., and Gugerli, P. 2015. Effects of Grapevine red blotch-associated virus on vine physiology and fruit composition of field grown grapevine cv. Gamay. Pages 234-235 in: Proc. 18th Congr. Int. Counc. Study Virus Viruslike Dis. Grapevine (ICVG), Ankara, Tukey.

Ribéreau-Gayon, P., Glories, Y., Maujean, A., and Dubourdieu, D., eds. 2006. Handbook of Enology: Vol. 2. The Chemistry of Wine-Stabilization and Treatments, second ed. Wiley, Chichester, U.K.

Ricketts, K. D., Gómez, M. I., Fuchs, M. F., Martinson, T. E., Smith, R. J., Cooper, M. L., Moyer, M. M., and Wise, A. 2017. Mitigating the economic impact of grapevine red blotch: Optimizing disease management strategies in U.S. vineyards. Am. J. Enol. Vitic. 68:127-135.

Seguin, J., Rajeswaran, R., Malpica-Lopez, N., Martin, R. R., Kasschau, K., Dolja V. V., Otten, P., Farinelli, L., and Pooggin, M. M. 2014. De novo reconstruction of consensus master genomes of plant RNA and DNA viruses from siRNAs. PLoS One 9:e88513.

Sudarshana, M. R., Perry, K. L., and Fuchs, M. F. 2015. Grapevine red blotchassociated virus, an emerging threat to the grapevine industry. Phytopathology 105:1026-1032.

Szychowski, J. A., Doazan, J. P., Leclair, P., Garnier, M., Credi, R., Minafra, A., DuranVila, N., Wolpert, J. A., and Semancik, J. S. 1991. Relationship and patterns of distribution among grapevine viroids from California and Europe. Vitis 30:25-36.

Varsani, A., Roumagnac, P., Fuchs, M., Navas-Castillo, J., Moriones, E., Idris, A., Briddon, R. W., Rivera-Bustamante, R., Murilo Zerbini, F., and Martin, D. P. 2017. Capulavirus and Grablovirus: Two new genera in the family Geminiviridae. Arch. Virol. 162:1819-1831.

Visser, M., Burger, J. T., and Maree, H. J. 2016. Targeted virus detection in nextgeneration sequencing data using an automated e-probe based approach. Virology 495:122-128.

White, T. J., Bruns, T., Lee, S., and Taylor, J. 1990. Amplification and direct sequencing of fungal ribosomal RNA genes for phylogenetics. Pages 315-322 in: PCR Protocols: A Guide to Methods and Applications. D. G. M. Innis, J. Sninsky, and T. White, eds. Academic Press, Orlando, FL.

Zerbino, D. R., and Birney, E. 2008. Velvet: Algorithms for de novo short read assembly using de Bruijn graphs. Genome Res. 18:821-829.

Zheng, Y., Gao, S., Padmanabhan, C., Li, R., Galvez, M., Gutierrez, D., Fuentes, S., Ling, K.-S., Kreuze, J., and Fei, Z. 2017. VirusDetect: An automated pipeline for efficient virus discovery using deep sequencing of small RNAs. Virology 500:130-138.

Zufferey, V., Cochard, H., Ameglio, T., Spring, J. L., and Viret, O. 2011. Diurnal cycles of embolism formation and repair in petioles of grapevine (Vitis vinifera cv. Chasselas). J. Exp. Bot. 62:3885-3894. 